\title{
Religious Values in Kitab Kalam Qodrat Manuscript as Literary Heritage
}

\author{
Anugrah Putri Juniarti ${ }^{1}$, Kundharu Saddhono ${ }^{2}$, and Prasetyo Adi Wisnu Wibowo ${ }^{3}$ \\ $\left\{\right.$ pj_anugrah@student.uns.ac.id ${ }^{1}$, kundharu_s@staff.uns.ac.id ${ }^{2} \&$ \\ prasetyoadiwisnuwibowo@yahoo.co.id ${ }^{3}$ \} \\ ${ }^{1,2,3}$ Universitas Sebelas Maret, Surakarta, Indonesia
}

\begin{abstract}
Moral deterioration is problems that can be found easily in the latest generation. Lack of respect towards teachers, dishonesty, and cheating are some of the examples of moral deterioration among students. One way to overcome those problems is by adopting the values that can be found in Macapat songs, since Macapat songs cannot only be used as a source of entertainment, but also have a very noble value (adiluhung). This study focuses on analyzing some values contained in Kitab Kalam Qodrat (KKQ) manuscript which can be used as the material to teach students in term of shaping their attitude. This study uses content analysis as its method. All of the data gathered then analyzed qualitatively. The findings show that KKQ manuscript can be used as the material to shape students' attitude, since it contains valuable religion principles and values including aqeedah (values of belief) and akhlaq (moral).
\end{abstract}

Keywords: religious values, macapat, aqeedah, akhaq

\section{INTRODUCTION}

Macapat song is one form of literature that is not only enjoyed as entertainment, but also has positive values that can be used in communities [6]. There are at least seven function of Macapat, including as the source of entertainment, as storage for Javanese local wisdom, as a source to generate heroism, education, history, sorcerous, and religion values [7]. Vocalized Macapat is one of the art forms that is developed among communities, e.g. Javanese community [8]. Hence, it is not difficult for the community to be able to enjoy and understand Macapat. In addition, Macapat has values and messages that can be adapted in society [4]. Javanese knowledge and local wisdom that is often known as piwulang, that contained in the Macapat song are also universal, hence, the values contained in the Macapat song cannot only be applied by the Javanese community, but also by others [9]. The values of divinity, leadership, politeness, and devotion to parents are some examples of local wisdom values that can be adapted through Macapat songs [10] [4]. Therefore, in addition to being an entertaining medium, Macapat songs also have important noble values in shaping ones' characters [6].

Another reason why Macapat can be used to overcome moral deterioration is because every product of Javanese culture has the characteristic called adiluhung, a noble value [11] [12]. Wibowo in his study mentioned that any cultural products that has adiluhung as its characteristic, can be used as a way in shaping characters [13]. Hence, Macapat is included in 
one of the materials that can be used as a guideline for society and communities. Although, many values are offered in the Macapat that does not mean that it is attractive to the millennial generation [6]. The reason is because many songs of Macapat use vocabularies that are relatively difficult to understand, hence it is considered to be less suitable for the present generation. The reality in today's society shows that the millennial generation tends to enjoy western music or songs more than traditional songs, including Macapat songs because western songs are considered more modern, catchy, and easily understood [14].

One of the Macapat songs that is densed with religious values is Kitab Kalam Qodrat manuscript (hereinafter abbreviated as KKQ). This Mpu Tantular Sidoarjo's manuscript collection is in the form of a Macapat song, and written in Pegon Arabic letters which speaks Javanese. Also, there are few parts of Arabic in some propositions and quotations from several Islamic holy books. Pegon Arabic is used in the making of literary works of Islamic based, including KKQ [15]. KKQ is a Javanese manuscript containing the saga of the Arabian King named Imam Sujana, who fought against the heathens, in which there are many quotations mentioned from the Qur'an and other Islamic books [16]. There are many lessons that can be learned from the manuscript, which include the prohibition of being arrogant, good householder procedures, wife etiquette towards husband, the knowledge about Faith, Tawheed and Ma'rifat [16]. Based on its form, the letter used, as well as the messages contained in the KKQ manuscript, shows that this manuscript is an Islamic Javanese literary work that is dense of religious values. In addition, in terms of the language used, in contrast to some existing songs, the language used in the songs on the KKQ manuscript is not difficult to understand, hence millennials could easily comprehend.

Based on the reasons above, this study focuses on analyzing KKQ, in which the results can be used as teaching materials for students. Religious value is one of the values that includes in character education, in which basically the focus of this research. The reason is because religious principles can be an effective solution in overcoming moral degradation among millennials, such as juveniles [1]. Islamic religious values are used as a reference in analyzing the KKQ because the content of the manuscript is related to the values of Islam. The basic competencies of spiritual attitudes and social attitudes must be possessed by students at each grade level [17]. Therefore, to fulfill the competencies of the spiritual and social attitudes of students, materials that contain religious values are needed. However, since the focus of this research is to find religious values to make it as teaching material to shape the character of students, this analysis later is limited to religious values related to aqeedah (faith in God) and akhlaq (moral values).

\section{METHOD}

The main data source of this study is based on the combination of both translation study finished by Sri Sulistianingsih (2016) and the origin copy of KKQ manuscript of Mpu Tantular's museum collection. That was to ensure that the manuscript translation had been cleared off from errors. This research uses content analysis research method, which is a form of research that aims to produce objective and systematic descriptions of the content and meaning contained in communication media [18][19][20]. The data analysis in this study was interactive analysis technique. Interactive analysis is a technique that can be done by putting the following 3 analysis components in sequence; data reduction, data presenting, and concluding data [21]. There are at least 6 processes for collecting data and analysis from this study. The process is as follows; unitizing, sampling, recording/coding, reducing data to manageable representation, abductively inferring contextual phenomena, narrating the answer to the research question. 
Unitizing, sampling, recording, and reducing data to manageable representation is a unit of process called data making [19]. Unitizing is the process of classifying parts of documents systematically, according to the desired classification form. Sampling is the process of taking quotes from a text or document, where the quotations can represent the population of data to be analyzed. Recording/coding is the process of converting text to be easily understood and analyzed. Abductively inferring contextual phenomena is a process of analysis carried out by the researchers, in accordance with the appropriate context contained in the document itself. Narrating the answer to the research question is the process of informing the data of the analysis, hence, it becomes easy to comprehend of a research report [19]. After all the data making processes carried out, researchers then analyze the data obtained using qualitative approach.

\section{RESULT AND DISCUSSION}

KKQ, which is around 80-90 years old and the author is anonymous, consists of 32 pupuh [16]. Pupuh, is a collective tembang macapat that has same type [10]. Each pupuh in Macapat consists of one collection of the same type of Macapat. Many believe that KKQ contains messages that can used as beacon for people. Some of the macapat that can be found in KKQ include; pupuh asmaradana, sinom, durma, pangkur, dandhanggula, kinanthi, megatruh, mijil, maskumambang, and pucung.

From the saga in the KKQ, there are messages that can be adapted as guidelines for people. Religious value is the most prominent value in the KKQ, although there are also other values that can be taken such as didactic values, heroism and much more [16]. When one is reading an Islamic Javanese literature, the religious element can immediately be seen in the first pupuh, in the first stanza which is marked by the appearance of wandana (opening verse, which is in line with manggala in ancient Javanese literature) which mostly is in form of asmaradana song, and contains praise and worship to God and mentioned the traits of God [15].

In wandana from Islamic Javanese manuscript, there are values that can be taken, such as we are suggested to always remember God in every occasion. This shows that the manuscript itself is basically Islamic based. In addition, there is a depiction of the God's attributes, which becomes basic knowledge and form of hope on how to get love and forgiveness by God. God in this pupuh is called Sukma. Sukma is another term in mentioning God in Javanese community, besides Hyang, Hyang manon, Hyang widi etc.

\subsection{Aqeedah Values}

Aqeedah is a matter that must be believed by heart, held firmly and believed without any doubts, which results may bring calm to those who do [22]. A true practice of aqeedah will make mind and heart calm, which may save humanity from errors and polytheism. In addition, aqeedah is also influential in shaping children's attitudes and behavior. When tauhid is firmly embedded into mind and heart, it will become a formidable inner strength. Hence, that may give a positive attitude that would have an impact on both the individual and the people around.

\subsubsection{Faith in God}

The base of each believer is to believe to God which means the value of having faith to God is important to have by each and every person that worships God, as stated in the quote of KKQ manuscript below:

Kang iman pangestu neki/ Teges tauhid punika/ Ngestuaken pangerane/ Pangeran ingkang amurba/ kang masesa ing sira/ Tegese ma'rifat iku/ Tunggal jatining Pangeran// (VII

Asmaradana, verse 18, line 1-7)

Translation: 
Faith means to believe, Tauhid means to believe in God (Allah), God the Almighty, who rules you, makrifat is real and one with God.

In the quote above, it can be learned that faith is an important value for every human being who believes in God. The reason is because having faith is believing. Belief is the initial foundation of every religion. Faith in Islam is described in a scientific discipline that is often known as Tauheed. Tauheed is the main foundation in religious concepts, because learning Tauheed is understanding of the monotheism of Allah [23].

In addition, the quote also mentioned about makrifat, in which makrifat in Sufism is one of the stages that all human must go through to achieve perfection. These stages consist of syariah, tarekah, hakekah and makrifah [24]. It is also mentioned that makrifah is a condition when one is united and being one with God [25]. mentioned that makrifah is the highest stage in religion, obtained through various preparations and special prayers that are able to bring people to meet God by heart (manunggaling Gusti). This proves that to reach makrifah, one must have faith and belief in God.

\subsection{Moral Values (Akhlak)}

Morals are behavioral patterns that accumulate aqeedah (belief in God) and syariah (obedience to God) hence merit behaviors can be achieved [26]. Javanese is a religious society, in which there is a fairly well-known expression says "pracaya lan mituhu marang hyang manon" (believing and being obedient to God). That Javanese expression shows that after one believes in God (pracaya), then that belief must be indicated by obedient (mituhu) to all His commands and prohibitions. One way to prove it is to become the human being manungsa kang utama who shows good characteristics and behaviors. Morals (akhlak) emphasizes on attitudes and behaviors which describe values that must be owned and used as habits by students in every day's life [27]. Honesty, trustworthy, sincerity, patient, always grateful, optimistic, helpful, forgiving, and more are the efforts to guard against evil deeds and sins, which is also a guidance to be a noble human being [27]. Moral values that intersect with the relationship between human beings and God is called hablum minallah, whereas what intersect with the relationship among human beings is called hablum minannas.

\subsubsection{Being Grateful and Praying to God}

Those who believe God as one and only creator of all things should know how to be grateful and pray to God, as stated in the quote of KKQ manuscript below:

Apan kinen sampun susah gusti/ Ing panduka rinebut ayuda/ Sang retna suka galihe/ Sukur

marang Yang Agung/ Anenedha marang Yang Widi/ Muga menang kang yuda/Gustiku sang

bagus/Sigegen wahu sang retna/Kawarnaha wong kafir tengara jurit/ Barise kafir tata// (XIII

Dhandhanggula, verse 23)

Translation:

Hence do not be troubled, shall you advance to war." The Queen is in Joy, being grateful and pray to Allah, "Wish you win the war my Lord." It was told that the infidels are hiding the signs of war, the infidels marched neatly.

The message that can be learned from the quotation above is to always be grateful. It can be seen from the figure of the wife of Raden Imam Sujana above, who is called sang retna. It can be seen that she was happy because she received conferment, hence she immediately thanked God. Moreover, sang retna was not drown in joy, but soon she said prayers to Hyang Agung (God) for safety and victory.

Gratitude is a moral that shows the expression of being thankful to God for the blessings that have been given. gratitude is mentioned 64 times in the Holy Qur'an. In Al-Baqoroh verse 152 
says, "Be thankful to Me and do not deny My favor" [29]. It can be learned that gratitude is God's command for all human. The purpose of gratitude is also stated in the Holy Qur'an, Surah Ibrahim verse 7, "If you are grateful, I will surely increase you [in favor]; but if you deny, indeed, My (God) punishment is severe." The quotation shows the importance of being grateful since God will add His blessings, yet punishment will come should one deny God's blessing. Gratitude can also be seen from Javanese society's life system. The form of gratitude for the Javanese community is not only expressed in utterances, but usually in various ceremonies $[12][30]$.

\subsubsection{Being Patient}

Being able to be patient to all the things that God has given is one prove that shows that we are an obedient believers, as stated in the quote of KKQ manuscript below:

Pinten-pinten sawek cinoba Yang Agung/Pra Nabi sedaya/Sami cinoba Yang Widi/Lamun

mantep ing coba angsala rahmat// (XXXII Pucung, verse 16)

Translation:

It may be a trial from God, all the Prophets get trials from God. If one is patient against temptation, shall he get mercy.

Based on the quote above, there is a religious value about patience. Patience is one of the morals that every individual must have. Moreover, it is explained that anyone who is patient will get mercy. Therefore, those who are patient in facing all trials from God will get His love and mercy. The promise of God mentioned in the KKQ is also found in Al-Baqoroh verse 155

"And we will definitely test you with a little fear, hunger, lack of wealth, soul, and fruits. And give good news to those who are patient. "

In addition, God's the promises of grace about patience is also found in the concept of Javanese social life. Many Javanese wise words that says such as "sabar iku subur" meaning that patience results in happiness; "wong sabar rejekine jembar" meaning that those who are patient will find fortune; and "sabar lan narima margining basukin ngangsa-angsa marakake brakala" meaning that patience and sincerity lead to salvation. Those sayings are basically the proofs that shows how important patience in the view of the Javanese community. Besides, all of the Javanese sayings points to the benefit that one will get should he be patient. Hence, the purpose of patience is not only based on the religious side, but in the aspects of the life of the Javanese people themselves.

\subsubsection{Communicate Delicately}

Generally, the way we speak shows how decent we are as human being, so does in religous community, as stated in the quote of KKQ manuscript below:

Abagus tur dadi Nabi/Sinungan kitab tarekat/Tur bagus alus tembunge/Lah ta iku ularana/

Matur kang pra ngulama/ Surat mariyam gonipun/ Inni ambeli min ladunka// (I

Asmaradana, verse 15, line 1-7)

Translation:

Handsome and become a prophet, he was given the book of Tarekat, besides his handsome looks and words, that is what you should make an example of, scholars said the examples is located in surah maryam Inni ambeli min ladunka.

The citation of Asmaradana song above shows that communicating gently is a commendable moral. This example can be taken from the figure of a prophet, a person who certainly has a high position not only in the views of mankind but also God. Although, he still respects others by saying respectful words. Fine speaking is one of the behaviors that shows manners [30].

In Javanese terms manners are known as tata krama. There are many types of manners. One of which is speaking manners. The Javanese community is a society known by its soft and 
delicate words as their mean of communication [31]. It is in fact illustrated in Javanese saying called unen-unen that says "ajining diri dumunung aneng lathi", which translate: self-quality is reflected in speech. This indicates that communicating by using delicate words will show our character and quality as a person who is polite, good mannered, and cultured. On the other hand, rude speaking reflects that the speaker is a person who is bad mannered, arrogant and disrespectful. Talking with gentle intonation is one way to respect the interlocutors. Delicate words are one of the moral values which relates not only to one another but also to God. As when we pray, we will be modest by using a soft voice, to show respect to God. This should work the same with others. By speaking delicately, the interlocutors will feel more respected.

\section{CONCLUSION}

It can be understood that the song contains expressions that become Javanese cognition systems and cultural symbols in the form of education or piwulang. Piwulang which is found to be related to religious education, including aqidah and akhlak. The values of the faith contained in the KKQ fiber include believing in God, then the moral values found are praying to God, being thankful, patient, resigned (resignation), saying soft words, and arrogant prohibitions. The values contained in the KKQ fiber besides being in accordance with the Javanese people's principles of life also in accordance with the teachings contained in the Koran are evidenced by the discovery of several prophetic stories originating from the Qur'an in the KKQ fiber. With its different presentation, the knowledge implied in the song later became Javanese local wisdom and culture. Piwulang found in KKQ fiber shows values that are in accordance with the character criteria needed by humans, so that the religious values contained in the KKQ fiber can be used as material to build character.

\section{REFERENCE}

[1] Nwankwo, Samuel C. „Religious Boom and Moral Decadence In Nigeria: Implications For National Development.“ International Journal of Theology and Reformed Tradition, Vol.7, 2015.

[2] Nuriman, Fauzan. "The Influence of Islamic Moral Values on the Student's Behavior in Aceh.“ Dinamika Ilmu, 17( 2), pp.275-290, 2017. DOI: 10.21093/di.v17i2.835

[3] Barakat, Ibrahim. "Value Re-Orientation: A Strategy for Combating Moral Decadence among Students of Tertiary Institutions in Nigeria. IOSR Journal Of Humanities And Social Science (IOSR-JHSS). 23(07), pp. 81-85, 2018. DOI: 10.9790/0837-2307068185

[4] Wangsa, Bremara Sekar, Suyanto, Sulistyo Edi Tri. "A Study on Noble Values of Tembang Macapat Kinanthi in Serat Wulangreh by Pakubuwono IV." Atlantis Press: Advances in Social Science, Education and Humanities Research (ASSEHR), Vol. 279, pp. 170-174, 2018.

[5] Saddhono, Kundharu and Pramestuti, Dewi. "Sekar Macapat Pocung: Study of religious values based on javanese local wisdom. “ Jurnal el Harakah, 20(1), pp. 15-32, 2018. DOI: 10.18860/el.v20i1.4724

[6] Basir, Udjang P M, Marifatulloh, Sayid. "The Art of Tembang Macapat: Exclusiveness of the Forms, Value Aspects, and Learning Approach." Atlantis Press: Advances in Social Science, Education and Humanities Research, vol. 222, pp. 226-230, 2018.

[7] Marsono. "Lokajaya.“ Disertasi, Yogyakarta: Pascasarjana UGM, 1996.

[8] Darmasti. "Kidung Kandhasanyata Sebagai Ekspresi Estetik Pesinden Wanita Mardusari.“ Harmonia Jounal of Art Research And Education, 11(2), pp. 180-190, 2011. DOI: 10.15294/harmonia.v11i2.2211 
[9] Budiono, Heru and Wiratama, Nara Setya. "Pendidikan Nilai Dalam Tembang Macapat Dhandanggula.“ Jurnal Penelitian Pendidikan, 9(1), pp. 1311-1374, 2017.

[10] Setiyadi, D. B. Putut. "Discourse Analysis Of Serat Kalatidha: Javanese Cognition System And Local Wisdom.“ Asian Journal Of Social Sciences \& Humanities, 2(4), pp. 292-300, 2013.

[11] Kismini, Elly. "Pengembangan Konservasi Budaya Kesenian Tradisional Tembang Jawa Di Sekolah.“ Jurnal Forum Ilmu Sosial, 39(1), pp. 1-11, 2012.

[12] Saddhono, Kundharu. "Membangun Kearifan Lokal Melalui Karya Sastra Dan Budaya Daerah [Jawa]. „Pros. Seminar Nasional Bahasa Dan Budaya, pp. 8-17, 2017.

[13] Wibowo, Prasetyo A W. "A Stylistic Study on the Literary Works of Ki Padmasusastra Holistic Critique Perspective.“ International Journal of Language and Linguistics, 2(5), pp. 139-150, 2015.

[14] Asfina, Risda and Ovilia, Ririn. "Be Proud of Indonesian Cultural Heritage Richness and Be Alert of Its Preservation Efforts In the Global World," Humanus: Jurnal ilmiah Ilmuilmu Humaniora, 15(2), pp.195-206, 2016. DOI: 10.24036/humanus.v15i2

[15] Purnama, S Bambang. “Kesastraan Jawa Pesisiran.” Surabaya: Kartika Mulya, 2011.

[16] Sulistianingsih, Sri. "Kitab Kalam Qodrat: Suntingan Teks Dan Kajian Struktural." Skripsi. Surabaya: FIB Universitas Airlangga, 2016.

[17] Kemendikbud. "Permendikbud No. 24 Tahun 2016 Tentang KI dan KD Kurikulum 2013 PendidikanDasar dan Pendidikan Menengah.” Jakarta: Kemendikbud, 2016.

[18] Santoso, Puji. "Metodologi Penelitian Sastra (Paradigma, Proposal, Pelaporan, dan Penerapan).“ Yogyakarta: Azzagrafika, 2015.

[19] Krippendorff, Klaus. "Content Analysis An Introduction to Its Methodology. “ London: Sage Publications, 2004.

[20] Ratna, Nyoman Kutha. "Sastra dan Cultural Studies: Representasi Fiksi dan Fakta."Yogyakarta: Pustaka Pelajar, 2008.

[21] Sutopo. „Metodologi Penelitian Kualitatif.“ Surakarta: UNS, 2006.

[22] Mayangsari, Galuh N K. "Pendidikan Aqidah Dalam Perspektif Hadits." Jurnal Transformatif (Islamic Studies). 1(1), pp.48-78, 2017.

[23] Solichah, Aas siti. “Teori-Teori Pendidikan Dalam Al-Qur'an.” Edukasi Islam, Jurnal Pendidikan Islam, 07(1), 2018.

[24] Kurnialoh, Nasri. "Nilai-Nilai Pendidikan Agama Islam Dalam Serat Sastra Gendhing." El-Harakah, 13(1), 2015.

[25] Endraswara, Suwardi. "Mistik Kejawen, Sinkrotisme, Simbolisme, dan Sufisme dalam Budya Spiritual Jawa. ” Yogyakarta: Narasi, 2006.

[26] Habibah, Syarifah. "Akhlak dan Etika dalam Islam. Jurnal Pesona Dasar, 1(4), pp. 73-87, 2015.

[27] Al Munawar, Said Agil. “Aktualisasi Nilai-Nilai Qur'ani.” Ciputat: Ciputat Press, 2005.

[28] Shobibah, Ida F. "Kebersyukuran (Upaya membangun Karakter Bangsa Melalui Figur Ulama)." Jurnal Dakwah, 15(2), pp. 383-407, 2014.

[29] Arinda R, Ichmi Yani. "Sedekah Bumi (Nyadran) Sebagai Konvensi Tradisi Jawa dan Islam Masyarakat Sraturejo Bojonegoro.“ Jurnal El Harakah, 16(1), pp. 100-110, 2014.

[30] Djuwita, Puspa. "Pembinaan Etika Sopan Santun Peserta Didik Kelas V Melalui Pembelajaran Pendidikan Kewarganegaraan Di Sekolah Dasar Nomor 45 Kota Bengkulu. “ Jurnal PGSD: Jurnal Ilmiah Pendidikan Guru Sekolah Dasar, 10(1), Pp. $27-$ 36, 2017. 
[31] K. Saddhono, "Cultural and social change of foreign students in Indonesia: The influence of Javanese Culture in Teaching Indonesian to Speakers of Other Languages (TISOL)." IOP Conf. Ser.: Ear. and Envi. Sci.. vol. 126 no. 1 IOP Publishing, 2018. 